\title{
Szekunder karbonátok mennyisége és vertikális eloszlása tokaji talajszelvényekben
}

\author{
NOVÁK Tibor József ${ }^{1}$, CsÁMER Árpád ${ }^{2}$, INCZE József ${ }^{1}$, PAPP István ${ }^{2}$, RózSA \\ Péter $^{2}$ \\ ${ }^{1}$ Debreceni Egyetem, Tájvédelmi és Környezetföldrajzi Tanszék, \\ ${ }^{2}$ Debreceni Egyetem, Ásvány- és Földtani Tanszék
}

\section{Bevezetés}

A tokaji Nagy-hegy talajainak kalcium-karbonát tartalom tekintetében is tapasztalható nagyfokú változatossága már a korai talajtani vizsgálatok eredményei alapján is felkeltette a figyelmet (SZABÓ, 1866; BITTÓ, 1898a-b; SIMKÓ, 1926). A hegyaljai nyirok talajok között a karbonát mentes szelvényektöl a földes részben (<2 mm) 30-35\% kalcium-karbonátot tartalmazó szelvényekig rendkívül különböző értékekkel találkozhatunk. Ugyanakkor figyelemre méltó a hegyen leírt talajszelvényekben előforduló másodlagos karbonát kiválások változatossága is. Jellemzőek a mészlepedékek, mész erek, az atkásság, a mészgöbecsek, löszbabák, de legsajátosabbak a talajban előforduló durva törmeléket bevonó, 1-7 mm vastagságú mészkérgek. Ezek eredetére vonatkozóan nyitott kérdéseket vet fel, hogy gyakran olyan szelvényekben is találkozhatunk jelentős mennyiségủ karbonát felhalmozódással, amelyekben a talajosodott szintek alatt csaknem karbonátmentes vulkáni kőzet, vagy annak málladéka helyezkedik el.

A tokaji Nagy-hegy dácit lávakőzetei karbonátot legfeljebb elenyésző mennyiségben tartalmaznak: 49 tokaji piroxéndácit főelem-összetételi kőzetelemzés átlagos $\mathrm{CO}_{2}$-tartalma $0,06 \%(\mathrm{~m} / \mathrm{m})$, azaz a karbonát-tartalom átlagosan $<0,1 \%$ (GYARMATI, 1977). A piroxéndácit lávatestek belsejét érintő vulkáni utómüködés hatására kialakult elváltozásoknál az agyagásványosodással, limonitosodással, kovásodással, hialit és kalcedon képződéssel szemben a karbonátosodás viszonylag ritka jelenség (RÓZSA \& KoZÁK, 1982). Emiatt a tokaji Nagy-hegy talajai, amelyek karbonát felhalmozódási szintje a földes részben esetenként 30\%-ot is meghaladó karbonátot, illetve konkréciók formájában megjelenő másodlagos karbonátokat is tartalmaznak (NovÁK ET AL., 2014), mindenképp figyelmet érdemelnek.

A vulkáni kőzetekre települő pleisztocén lösznek, illetve helyenként annak áthalmozott, törmelékkel, talajosodott rétegekkel kevert lejtőhordalékának átlagos $\mathrm{CaCO}_{3}$-tartalma 5-10\% közötti (PINCZÉS, 1954; KERÉNYI, 1994; SÜMEGI, 1995; SÜMEGI \& HERTELENDI, 1998).

Postai cím: NovÁk TIBOR JózSEF, Debreceni Egyetem, Tájvédelmi és Környezetföldrajzi Tanszék, 4010 Debrecen, Egyetem tér 1. pf. 9.;

Tel/Fax: 52-512-945, E-mail: novak.tibor@science.unideb.hu 
Talajrendszertani, taxonómiai szempontból a Nagy-hegy talajai eddig elsősorban a vulkáni kőzeteken kialakult talajok osztályozási kérdései kapcsán kerültek a figyelem középpontjába. A vulkáni kőzetmálladékon kialakult nyirok talajokat BALLENEGGER (1917) fosszilis (preglaciális) eredetűnek tartja. Agyagtartalmuk, vízgazdálkodásuk vizsgálata a későbbiekben is az érdeklődés középpontjába került (FEKETE ET AL. 1997, STEFANOVITS, 1959). A World Reference Base (WRB) szerinti osztályozásuk kérdéseivel többen is foglalkoztak (FEHÉR, 2006; FÜLEKY ET AL., 2004; 2007; MADARÁSZ ET AL., 2013).

Tanulmányunkban a Nagy-hegy különböző talajképző kőzeteken létrejött talajaiban előforduló másodlagos karbonátok mennyiségét a megvizsgált talajszelvények litológiai viszonyainak tükrében értékeltük. Célunk az volt, hogy a földes részben, a konkréciókban, illetve a vázrészek felületére rakódott kérgek formájában felhalmozott pedogén karbonátok mennyiségét megbecsüljük, szelvénybeli vertikális eloszlásukat vázoljuk az eltérő alapkőzeten kialakult talajokban. További célunk volt, hogy az itt felsorolt karbonátformák ásványtani vizsgálatával azok eredetének tisztázatlan kérdéseire is ráirányítsuk a figyelmet.

\section{Anyag és módszer}

Vizsgálatunk során a Nagy-hegyen 20 talajszelvényt tártunk fel, amelyeket a WRB talajosztályozásra vonatkozó irányelvek (FAO 2006, IUSS WG - FAO 2007, 2014) szerint írtunk le és osztályoztunk. A szelvényekből talajszintenként gyüjtöttünk mintákat. A mintákban meghatároztuk a vázrész $(>2 \mathrm{~mm})$ arányát, a földes rész $(<2 \mathrm{~mm})$ szemcseösszetételét, a pH-t $\left(\mathrm{pH}_{\mathrm{H} 2 \mathrm{O}}, \mathrm{pH}_{\mathrm{KCl}}\right)$ a humusz-tartalmat (PONOMEROVA \& PlotNIKOVA, 1980), és kalcium-karbonát-tartalmat. Szintenként 3 bolygatatlan minta segítségével meghatároztuk az egyes talajszintek átlagos térfogattömegét. A mechanikai összetétel jellemzéséhez a vázrész nagyobb elemeinek $(>5 \mathrm{~cm})$ mennyiségét terepen történő szétválogatással, a kisebb darabok elkülönítését laboratóriumban száraz szitálással végeztük. A 2-0,2 mm közötti frakciók szétválasztását nedves szitálással, a 0,2 mm-nél kisebb frakciókat iszapolással (PANSU \& GAUTHEYROU, 2006) különítettük el.

A karbonátok koncentrációját és mennyiségét egy kiválasztott szelvényben három frakcióra elkülönítve becsültük: külön határoztuk meg a földes rész, a karbonát konkréciók (túlnyomóan a vázrész felületén bevonatként megjelenő karbonátos kéreg) és a vázrész (dácit) $\mathrm{CaCO}_{3}$-koncentrációját, majd mennyiségét.

A földes részből végzett $\mathrm{CaCO}_{3}$-koncentráció meghatározás esetében a szerves anyagot a mintákból elözetesen $\mathrm{H}_{2} \mathrm{O}_{2}$ kezeléssel eltávolítottuk. A tömbökről leválasztott karbonátos kérgek $\mathrm{CaCO}_{3}$-koncentrációját 7 darab, előzetesen gépi, majd kézi achátmozsárban porított mintából mértük. A vázrészt jellemző karbonát koncentráció becsléséhez a tömböket, blokkokat a karbonátos kéregtől megtisztítva készítettük elő. Ehhez szintenként 7 mintát Fritsch-féle pofás törőben 4-5 mm-es darabokra törtünk, majd acélmozsárban aprítottuk tovább, ezt követően gépi, majd kézi achátmozsárban porítottuk. A karbonátok koncentrációjának mérését mindhárom frakció (földes rész, karbonát kérgek és vázrész porítmánya) esetében volumetrikus méréssel (CHANEY \& DEMARS, 1982) végeztük, és $\mathrm{CaCO}_{3}$ - 
egyenértékben, \%(m/m)-ban adtuk meg. A felszínhez közeli talajszintekben, ahol a vázrész csupán kis számú, néhány mm átmérőjü, apró kavics formájában volt jelen, a vázrész és az azt bevonó karbonát kéreg nem volt szétválasztható. Ebben az esetben a vázrészt a kéreggel együtt porítottuk, és így végeztük el a karbonát meghatározást, 7 mintából.

A földes részben található karbonátok mennyiségének becslését a földes részben szintenként meghatározott térfogattömeg, a szint vastagsága, valamint az előzetesen meghatározott $\mathrm{CaCO}_{3}$ koncentráció $(\% \mathrm{~m} / \mathrm{m})$ ismeretében becsültük.

A kéreg formájában található karbonátok mennyiségét a vázrészek szintenként összegzett, számított felületének, a kérgek vastagságának és a kéregből előzetesen meghatározott karbonát koncentráció (\%) szorzataként számítottuk ki. Ehhez szükségünk volt a mészkérgek átlagos vastagságának és felületi kiterjedésének meghatározására is. A kérgek vastagságát a leválasztott kérgeken tolómérővel 0,1 $\mathrm{mm}$ pontossággal végzett harminc mérés átlagértékével becsültük. A vázrészben található tömbök, blokkok felszínét azonos tengelyhosszúságú ellipszoidok felszínével közelítettük (SA). Szintenként 10 jellemzö méretü, kéreggel bevont tömb, blokk esetében megmértük a tér három irányában a tengelyhosszúságot $(\mathrm{a}, \mathrm{b}$, c), majd felszínüket a Knud Thomsen formulával (XU ET AL., 2009) számítottuk ki:

$$
S A=4 \cdot \pi \cdot\left(\frac{a^{p} \cdot b^{p}+a^{p} \cdot c^{p}+b^{p} \cdot c^{p}}{3}\right)^{1 / p}
$$

ahol

$\mathrm{p} \approx 1,6075$

A vázrészben lévő karbonátok mennyiségét a talajszintek vázrész-tartalma (v/v\%), a vázrészből meghatározott térfogattömeg $\left(\mathrm{g} / \mathrm{cm}^{3}\right)$ és a vázrészből mért karbonát-koncentrációk alapján számítottuk. Ehhez a dacit tömbökből 30 minta esetében térfogattömeg meghatározást végeztünk.

A mennyiségi számítást mindhárom frakció esetében a teljes szelvényre vonatkozóan, a szintekre kapott értékek összegzéseként is elvégeztük az alábbiak szerint:

$$
\mathrm{IOC}_{\mathrm{p}} \text { stock }=\sum_{\mathrm{i}=1}^{\mathrm{n}} \mathrm{IOC}_{\mathrm{if}} \cdot \mathrm{bd}_{\mathrm{i}} \cdot \mathrm{d}_{\mathrm{i}} \cdot\left(1-\frac{\mathrm{cf}_{\mathrm{i}}}{100}\right)+\sum_{\mathrm{i}=1}^{\mathrm{n}} \mathrm{IOC}_{\mathrm{icr}} \cdot \mathrm{CR}_{\mathrm{i}}+\sum_{\mathrm{i}=1}^{\mathrm{n}} \mathrm{IOC}_{\mathrm{icf}} \cdot \mathrm{CF}_{\mathrm{i}}
$$

Ahol

$$
\begin{aligned}
& \mathrm{IOC}_{\mathrm{p}} \text { stock }=\mathrm{a} \text { teljes szelvényben felhalmozott szervetlen karbonát } \\
& \text { mennyisége }\left(\mathrm{kg} / \mathrm{m}^{2}\right) \\
& \mathrm{IOC}_{\mathrm{if}}=\mathrm{a} \text { szervetlen karbonátok koncentrációja a földes részben az i } \\
& \text { talajszintben }(\mathrm{m} / \mathrm{m} \%)
\end{aligned}
$$


$\mathrm{IOC}_{\mathrm{icr}}=$ a szervetlen karbonátok koncentrációja a karbonát kérgekben az i talajszintben $(\mathrm{m} / \mathrm{m} \%)$

$\mathrm{IOC}_{\text {iff }}=$ a szervetlen karbonátok koncentrációja a karbonát kérgekben az i talajszintben $(\mathrm{m} / \mathrm{m} \%)$

$\mathrm{bd}_{\mathrm{i}}=$ térfogattömeg az i talajszint földes részében $\left(\mathrm{t} \mathrm{m}^{-3}\right)$

$\mathrm{d}_{\mathrm{i}}=\mathrm{az}$ i talajszint vastagsága $(\mathrm{m})$

$\mathrm{cf}_{\mathrm{i}}=\mathrm{a}$ durva vázrész aránya az i talajszintben $(\mathrm{v} / \mathrm{v} \%)$

$\mathrm{CF}_{\mathrm{i}}=$ a durva vázrész térfogata az i talajszintben $\left(\mathrm{m}^{3}\right)$

$\mathrm{CR}_{\mathrm{i}}=$ a karbonátos kérgek térfogata az i talajszintben $\left(\mathrm{m}^{3}\right)$

A vázrészeket bevonó karbonátos kérgekből a Miskolci Egyetem ÁsványtaniFöldtani Intézetének laboratóriuma készített vékonycsiszolatokat, amelyekről a DE Ásvány- és Földtani Tanszékén mikroszkópos vizsgálatnak vetettünk alá. Az ásványfázisok minőségének meghatározása céljából egyes mintákon a DE Ásványés Földtani Tanszékén termoanalitikai vizsgálatot (TG, DTG, DTA) végeztünk. Ehhez a földes részek átlagolt porítmányát, illetve szitával leválasztott, $64 \mu \mathrm{m}$-nél kisebb frakciót is felhasználtuk. A vizsgálat Derivatograph-C (MOM) típusú készülékkel, $25-1000{ }^{\circ} \mathrm{C}$ hevítési intervallumon, $10{ }^{\circ} \mathrm{C} \cdot \mathrm{min}^{-1}$ hevítési sebességgel, $\mathrm{Al}_{2} \mathrm{O}_{3}$-kerámia tégelyben, légköri nyomáson, statikus levegő atmoszférában készült.

\section{Eredmények}

A szelvények egy részében ( 8 szelvény) a talajképző kőzet a teljes feltárt mélységben viszonylag homogén volt: lösz, illetve áthalmozott, részben talajosodott lösz rétegek, kolluviális lejtöüledékek, amelyek durva vázrészeket nem, vagy csak elenyésző arányban tartalmaztak. A szelvények másik részében (12 szelvény) a talajképzödés által érintett mélységen, azaz mintegy 100-150 centiméteren belül kőzettani folytonossági hiány jelentkezett, amennyiben a löszt, áthalmozott löszt és a kolluviális lejtőüledéket sekély mélységben a vulkáni kőzetmálladék (nyirok) vázrészekkel vegyes anyaga váltotta fel. A vázrészek aránya ebben az esetben a vulkáni kőzetekkel határos átmeneti rétegekben az 50\%-ot is meghaladta. Ugyanakkor a földes rész textúrájában a vulkáni kőzetmálladékon fejlödött szelvényekben nagyobb homok $(28.5 \pm 7 \%)$, és agyagtartalom $(10.9 \pm 4 \%)$, illetve a kőzetliszt, iszap frakció kisebb aránya $(60.6 \pm 6 \%)$ volt jellemző (1. táblázat). Ezzel szemben a löszön kialakult talajokban tapasztalható homok- $(15.5 \pm 3 \%)$ és agyagtartalom $(8.4 \pm 3 \%)$ kisebbnek, míg az iszapfrakció aránya nagyobbnak (76.1 $\pm 2 \%)$ bizonyult. A két szelvénytípus között a földes rész textúrájában és a karbonát-tartalomban mutatkozó különbségeket az 1. táblázat foglalja össze. 


\section{1. táblázat}

A mechanikai összetétel és a $\mathrm{CaCO}_{3}$-tartalom értékei (átlag士szórás) tisztán löszön kialakult ( $\mathrm{N}=17)$, illetve lösz-nyirok kőzethatárt tartalmazó $(\mathrm{N}=15)$ talajszelvényekböl származó mintákban

\begin{tabular}{|c|c|c|c|c|}
\hline \multirow[t]{4}{*}{ Minta típusa } & \multicolumn{3}{|c|}{ A földes rész $(<2 \mathrm{~mm})$ szemcseösszetétele } & \multirow{2}{*}{$\begin{array}{l}\mathrm{CaCO}_{3^{-}} \\
\text {ekvivalens } \\
\text { karbonát } \\
\text { tartalom }\end{array}$} \\
\hline & $\begin{array}{l}\text { Homok } \\
0,063-2 \mathrm{~mm}\end{array}$ & $\begin{array}{l}\text { Közetliszt } \\
0,002-0,063 \\
\text { mm }\end{array}$ & $\begin{array}{l}\text { Agyag } \\
<0,002 \mathrm{~mm}\end{array}$ & \\
\hline & $\%(\mathrm{~m} / \mathrm{m})$ & $\%(\mathrm{~m} / \mathrm{m})$ & $\%(\mathrm{~m} / \mathrm{m})$ & $\%(\mathrm{~m} / \mathrm{m})$ \\
\hline & \multicolumn{4}{|c|}{ 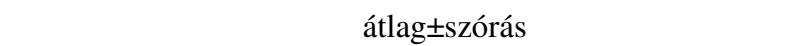 } \\
\hline $\begin{array}{l}\text { Löszön képződött } \\
\text { szelvényekből származó } \\
\text { minták }(\mathrm{N}=17)\end{array}$ & $15,5 \pm 2,8$ & $76,1 \pm 1,9$ & $8,4 \pm 2,6$ & $6,7 \pm 2,8$ \\
\hline $\begin{array}{l}\text { Lösz és nyirok határán } \\
\text { képződött szelvényekből } \\
\text { származó minták }(\mathrm{N}=15)\end{array}$ & $28,5 \pm 7,0$ & $60,6 \pm 6,5$ & $10,9 \pm 3,7$ & $18,1 \pm 10,4$ \\
\hline
\end{tabular}

A karbonátfelhalmozódás mennyisége, illetve vertikális helyzete alapján a vizsgált szelvények egy része Calcisol (T1, T3, T4, T5 szelvények), más része Cambisol (T8, T9, T11), illetve Regosol (T6, T12, T17a, T18) referencia csoportba sorolódott. Egyéb referencia csoportok (Chernozem, Phaeozem, Leptosol) kevesebb esetben fordultak elő. A karbonátok mennyiségi vizsgálata céljából részletesen megmintázott T18 szelvény Colluvic Regosolnak bizonyult. Pontos besorolása a talajképző üledék eredete, a karbonátok mennyisége, a talaj textúrája, és a teraszozott térszín alapján: Colluvic-Regosol (Calcaric, Siltic, Escalic).

A szelvényekben talált karbonát felhalmozódási formák rendkívül változatosak: mészhártyák, mészgöbecsek, löszbabák, mész-erek. A legsajátosabb formát azonban a talajban lévő vázrész felületére rakódott, kéregszerủ bevonatok jelentik. Ezek vastagsága 1-7 mm közötti, helyenként ágas, rücskös felülettel, borsókőszerü kifejlődéssel. Ezek mennyiségéhez képest az egyéb formában megjelenő másodlagos karbonátok mennyisége minden talajszintben elhanyagolható volt.

A talajminták földes részéből végzett karbonát meghatározás genetikai szintenként jelentős eltéréseket mutatott. Az A és $\mathrm{C}$ szintekben a földes rész karbonát tartalma alig haladta meg a 10\%-ot, míg az agyagosabb, kevesebb löszfrakciót tartalmazó $2 \mathrm{C}$ szintben $11,4 \%$-nak adódott. Ezzel szemben a $2 \mathrm{C} / \mathrm{R}_{\mathrm{k}}$ szintben 46,8\%-os karbonát tartalom mutatkozott. Ugyanitt találkozhattunk legnagyobb vastagságban, és legnagyobb mennyiségben a vázrészek felületét bevonó karbonátos kérgekkel, konkréciókkal (1. ábra). 


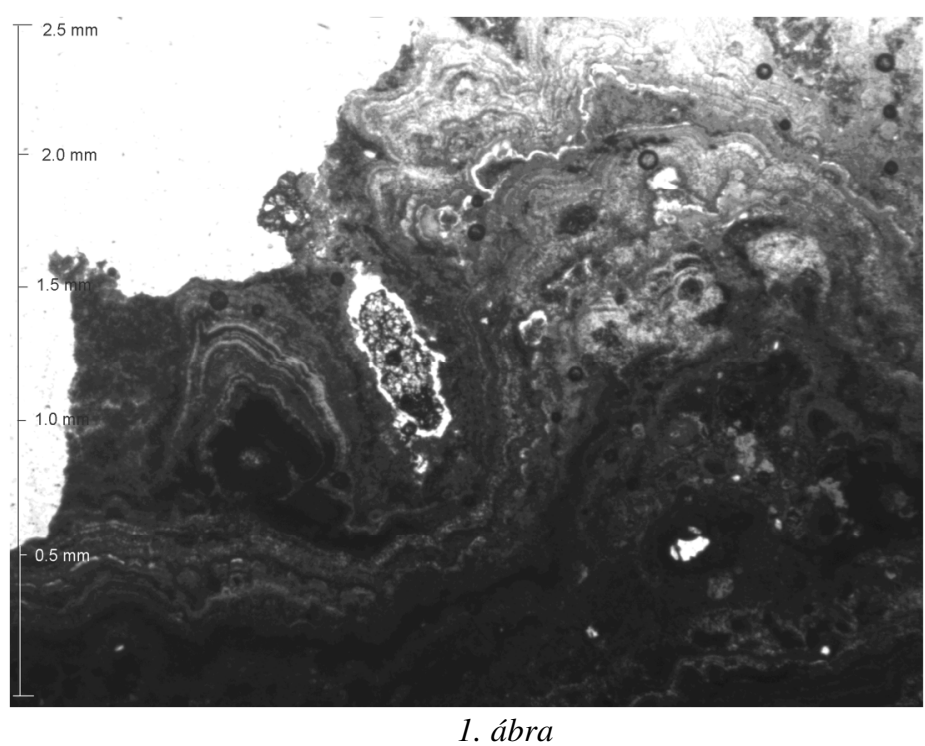

Szalagos karbonátkéreg vékonycsiszolati képe dácit vázrész felszínén

A volumetrikus meghatározással mért, $\mathrm{CaCO}_{3}$-egyenértékben kifejezett karbonát koncentráció a vázrészekből vett porított mintákban átlagosan $7,1 \pm 1,3 \%(\mathrm{~m} / \mathrm{m})$-nak, míg a vázrészek felületéröl leválasztott karbonátos kérgekben átlagosan 78,4 $\pm 15,8 \%(\mathrm{~m} / \mathrm{m})$-nak adódott. Nem találtunk igazán lényeges különbséget a részletesen mintázott T18 szelvény eltérő talajszintjeiből gyüjtött vázrész karbonát koncentrációjában, amely a $2 \mathrm{C}$ szintben $(90-150 \mathrm{~cm})$ $6,7 \pm 0,9 \%(\mathrm{~m} / \mathrm{m})$-nek, míg a $2 \mathrm{C} / \mathrm{R}_{\mathrm{k}}$ szintben $(150-180 \mathrm{~cm}) 7,3 \pm 1,4 \%(\mathrm{~m} / \mathrm{m})$-nak adódott. Ugyancsak nem volt jelentôs különbség a két eltérő talajszintben a kérgek karbonát koncentrációja tekintetében, amely a $2 \mathrm{C}$ szintben $81,0 \pm 13,7 \%(\mathrm{~m} / \mathrm{m})$-nek, míg a $2 \mathrm{C} / \mathrm{R}_{\mathrm{k}}$ szintben $76,8 \pm 18,3 \%(\mathrm{~m} / \mathrm{m})$-nak bizonyult.

A karbonát kérgek tömegének kiszámítására vonatkozó kalkulációnk eredményeként a $2 \mathrm{C}$ szintre $58,5 \mathrm{~kg} \mathrm{~m}^{-2}$, míg a $2 \mathrm{C} / \mathrm{R}_{\mathrm{k}}$ szintre $126,7 \mathrm{~kg} \mathrm{~m}^{-2}-\mathrm{t}$ kaptunk eredményül. Ez a kérgek átlagos $0,81 \%$ illetve $0,77 \%$ kalciumkarbonáttartalmával számolva 47,4 és $97,3 \mathrm{~kg} \mathrm{~m}^{-2}$ kalcium-karbonátnak felel meg.

A karbonátok egyes frakciókban (földes rész, vázrész és konkréciók) meghatározott koncentrációja, illetve a szint vastagsága és térfogattömege alapján kiszámított mennyiségét a 2. táblázat, szintenkénti megoszlásukat a 2. ábra mutatja be. 


\section{2. táblázat}

$\mathrm{A} \mathrm{CaCO}_{3}$ - egyenértékben kifejezett karbonát koncentrációja és mennyisége szintenként és frakciónkénti a T18 szelvényben

\begin{tabular}{|c|c|c|c|c|c|c|c|c|c|c|c|}
\hline \multirow{3}{*}{ 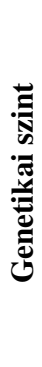 } & \multirow[b]{2}{*}{ 怘 } & \multicolumn{3}{|c|}{ Földes rész } & \multicolumn{3}{|c|}{ Vázrész } & \multicolumn{3}{|c|}{ Konkréciók (kérgek) } & \multirow{2}{*}{ 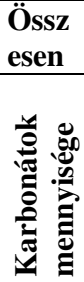 } \\
\hline & & o & 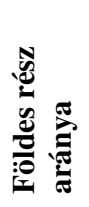 & 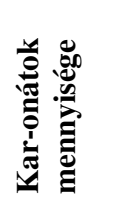 & 仓ْ & 氙 & 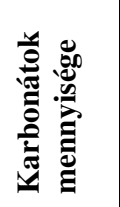 & 仓ْ & 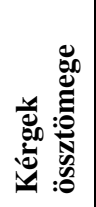 & 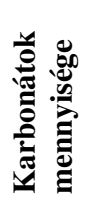 & \\
\hline & $\mathbf{c m}$ & $\begin{array}{l}(\mathbf{m} / \mathbf{m} \\
\%)\end{array}$ & $\begin{array}{l}(\mathrm{m} / \mathrm{m} \\
\%)\end{array}$ & $\mathrm{kg} \cdot \mathrm{m}^{-2}$ & $(\mathbf{m} / \mathbf{m} \%)$ & $\begin{array}{l}(\mathrm{m} / \mathrm{m} \\
\%)\end{array}$ & $\mathrm{kg} \cdot \mathrm{m}^{-2}$ & $\begin{array}{l}(\mathbf{m} / \mathbf{m} \\
\%)\end{array}$ & $\begin{array}{l}\mathbf{k g} \\
\cdot \mathbf{m}^{-2}\end{array}$ & $\begin{array}{l}\mathbf{k g} \\
\cdot \mathbf{m}^{-2}\end{array}$ & $\begin{array}{l}\mathbf{k g} \\
\cdot \mathbf{m}^{-2}\end{array}$ \\
\hline A & $\begin{array}{l}0- \\
15\end{array}$ & $9,2 \%$ & $\begin{array}{r}99,3 \\
\%\end{array}$ & 15,1 & $14,5 \%$ & $0,7 \%$ & 0,3 & $0,0 \%$ & 0 & 0 & 15,4 \\
\hline $\mathrm{C}$ & $\begin{array}{l}15- \\
90\end{array}$ & $10,2 \%$ & $\begin{array}{r}99,7 \\
\%\end{array}$ & 84,1 & $14,5 \%$ & $0,3 \%$ & 0,6 & $0,0 \%$ & 0 & 0 & 84,7 \\
\hline $\mathrm{C}$ & $\begin{array}{l}90- \\
150 \\
\end{array}$ & $11,4 \%$ & $\begin{array}{r}80,5 \\
\% \\
\end{array}$ & 60,5 & $6,7 \%$ & $\begin{array}{r}19,5 \\
\% \\
\end{array}$ & 16,3 & $81,0 \%$ & 58,5 & 47,4 & 24,2 \\
\hline $\begin{array}{l}\mathrm{C} / \\
\mathrm{R} \\
\mathrm{k}\end{array}$ & $\begin{array}{l}150 \\
- \\
180\end{array}$ & $46,0 \%$ & $\begin{array}{r}48,3 \\
\%\end{array}$ & 84,4 & $7,3 \%$ & $1,7 \%$ & 25,6 & $76,8 \%$ & 126,7 & 97,3 & 207,3 \\
\hline
\end{tabular}

Számításaink alapján az A, C, 2C szintekben az adott szint karbonát készletének legnagyobb része a földes részben található, míg a $2 C / R_{k}$ szint esetében a vázrészen kicsapódott kérgekben felhalmozott karbonát mennyiség meghaladja a földes részben lévő mennyiséget. Ez a kérgek korábban meghatározott karbonát tartalma alapján a $2 \mathrm{C}$ szintben $47,3 \mathrm{~kg} \mathrm{~m}^{-2}$, míg a $2 \mathrm{C} / \mathrm{R}_{\mathrm{k}}$ szintben $97.3 \mathrm{~kg} \mathrm{~m}^{-2}$ karbonátnak felel meg, miközben a földes részben a $2 \mathrm{C}$ szintben $60,4 \mathrm{~kg} \mathrm{~m}^{-2}$, a $2 \mathrm{C} / \mathrm{R}_{\mathrm{k}}$ szintben $84,3 \mathrm{~kg} \mathrm{~m}^{-2}$ adódott (2. táblázat). Az A és C szintben (0-15, és 15-90 $\mathrm{cm})$ előforduló vázrész esetében a kavicsok apró mérete miatt $(<15 \mathrm{~mm})$ az azokat bevonó kéreg nem volt szeparálható. Az együttesen készített porítmány karbonát koncentrációja 14,5 $11,5 \%$, amelyet a karbonátok mennyiségének kiszámítása során a vázrésznél vettuink tekintetbe. 


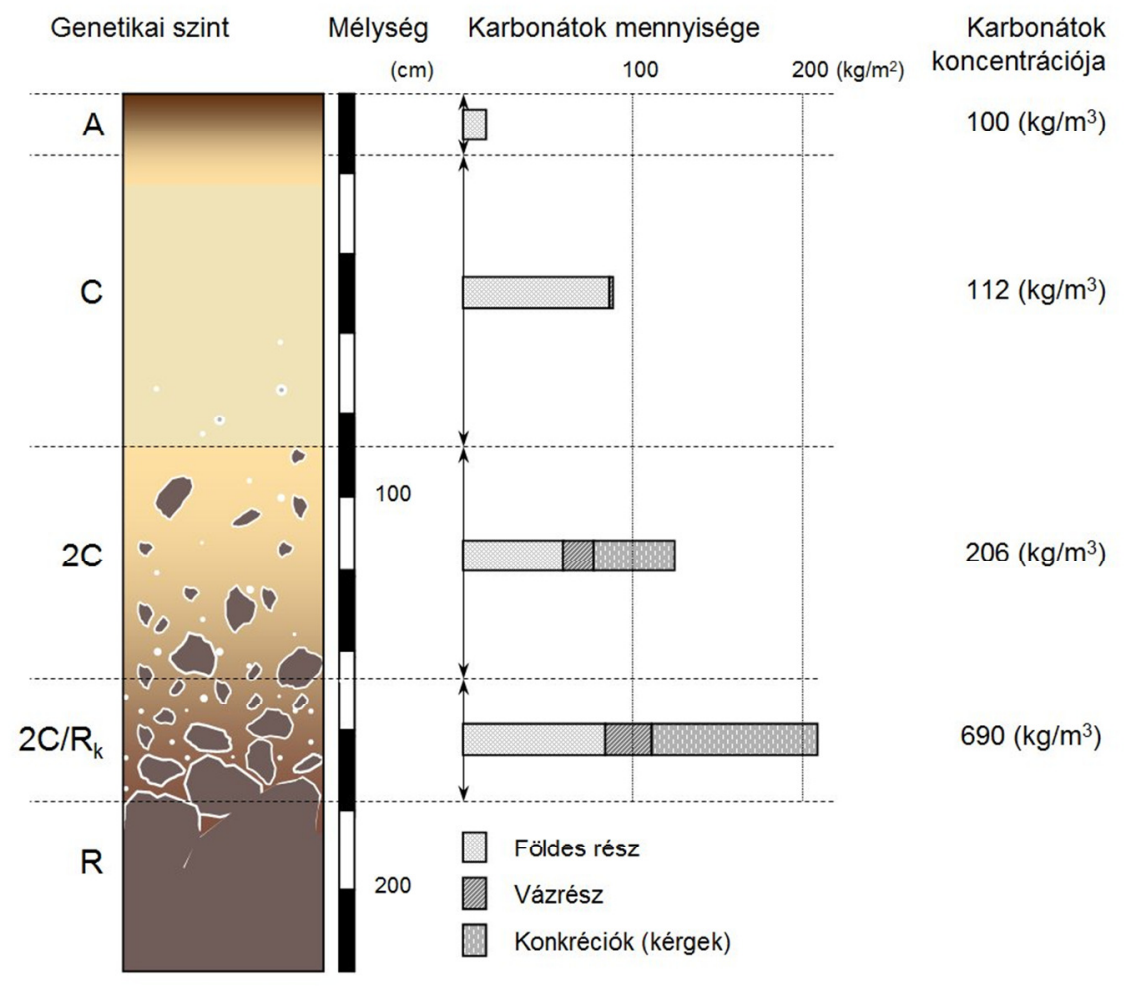

2. ábra

A T18 szelvény (Colluvic-Regosol (Calcaric, Siltic, Escalic) genetikai szintjei, a szintekben felhalmozott kalcium-karbonát mennyisége és koncentrációja.

Elméletileg a vázrészben tárolt karbonát készlet a talajtani folyamatok szempontjából kevésbé lényeges, ugyanis az irodalmi adatok alapján a mennyisége nem számottevő és az oldódása is lassan megy végbe. A vázrészek belsejének megnövekedett karbonát-tartalma ugyanakkor azt mutatja, hogy felhalmozódásuk nem csak a kőzetdarabok felületére korlátozódó folyamat eredménye. Ezt a mikroszkópos megfigyelések is megerősítik, ugyanis a kőzetszövet mikropórusait gyakran vékony lepedék borítja. Vázrészek polarizációs mikroszkópi vizsgálata szerint a kőzetben található hajszálrepedéseket kalcit tölti ki (3. ábra). Ezek a hajszálrepedések a karbonátos kéregből indulnak ki a kőzet belseje felé, ami szintén azt mutatja, hogy a karbonát nem a vázrészekből ered. 


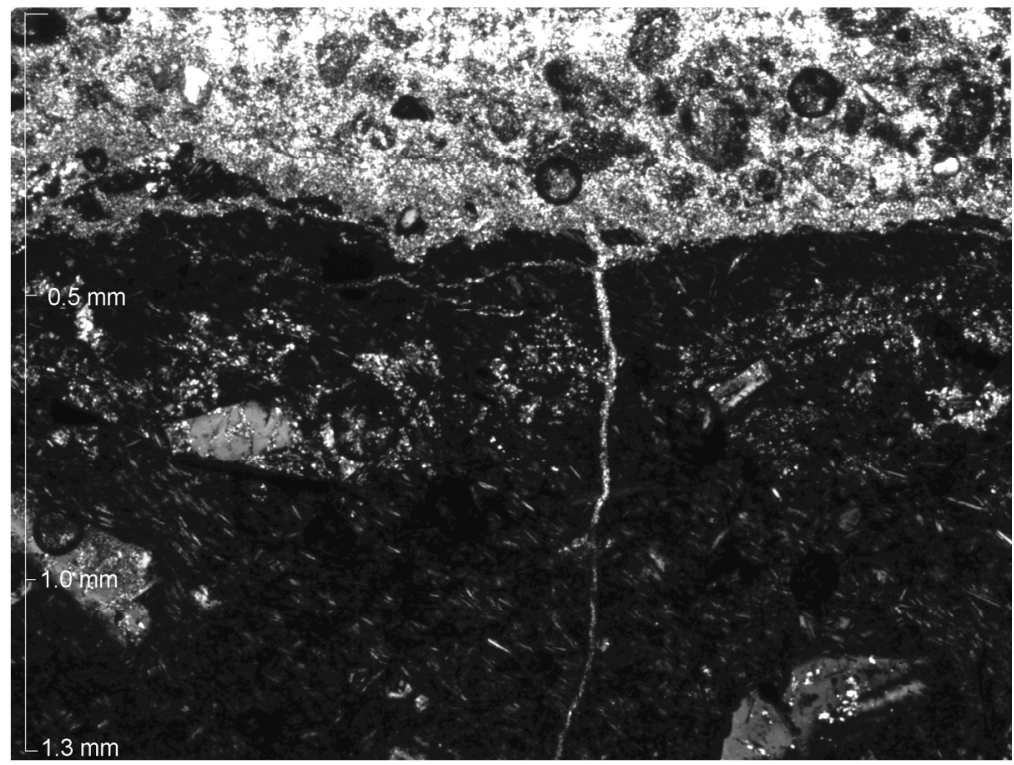

$$
\text { 3. ábra }
$$

Karbonátos kéregből a kőzet belseje felé kiinduló kalcitkitöltéses hajszálrepedés.

A termoanalitikai vizsgálattal kimutatható ásványos alkotók mennyisége és minősége tekintetében a talajszintek között nincs számottevő különbség, kivéve a karbonát-tartalmat. Lényegi eltérés az egyes minták földes része és $64 \mu$ m-nél kisebb frakciója között sem jelentkezett. Minden mintában kimutatható volt montmorillonit 20-50 \%, kaolinit 2-6 \% és szerves anyag 1-2 \% mennyiségben. A karbonát-tartalom 140-180 cm között két- háromszor nagyobb (20-40\%), mint a löszös részben (7-9\%). Ez azt jelentheti, hogy a szelvényekben a karbonát tartalom tekintetében jelentkező inhomogenitás elsősorban a karbonát kilúgzásnakkicsapódásnak köszönhető, míg az agyagásványos elbontódás ebben alárendelt szerepet játszik.

\section{Az eredmények értékelése}

Eredményeink azt mutatják, hogy a tokaji Nagy-hegy litológiai viszonyai mellett a vulkáni kőzetekre illetve azok málladékára települö lösz, és löszös üledékek miatt elöálló kőzettani folytonossági hiány, amely, mind a magasabb agyagtartalomban, mind a homokfrakció és a vázrész nagyobb arányában megmutatkozik, együtt jár a karbonátok felhalmozódásával is, ezért az ilyen szelvényekben rendre nagyobb karbonát tartalmat tapasztaltunk, mint a teljes mélységben löszön, illetve áthalmozott lejtöüledéken kialakult talajszelvényekben. A jelenség oka feltehetően a permeabilitási viszonyok megváltozása az eltérő litológiai adottságú rétegek határán. A határvonal talajszintbeli mélységében 
különböző formában előforduló másodlagos karbonát konkréciók jelennek meg, miközben a földes rész karbonáttartalma is eléri, vagy meghaladja a Calcic szintek határértékét jelentő 15\%-ot. Amennyiben ez a talajszint a felszíntől számított 100 cm-en belül fordul elő, akkor a talaj Calcisol referencia csoportba tartozása vagy a Calcic minősítő hozzáadásával a talajok osztályozásában is kifejezésre jut. A másodlagos karbonátok felhalmozódásának forrását, talajvíz hiányában, a feltalajból kilúgzással mélyebbre mosódó, majd kicsapódó karbonátokban kell keresnünk. Megfigyeléseink szerint azonban a jelenlegi klíma és domborzat mellett nem jellemző a szelvények rendszeres, mély átnedvesedése, amely a karbonátok ilyen mértékủ mobilizálódásának feltétele, ezért közvetítő közeg hiányában jelentős karbonát-fluktuáció sem valószínüsíthető. Számításaink szerint a karbonát felhalmozódásának zónájában jelenleg mintegy 2,5-szer több kalcium-karbonát raktározódik, mint a felette elhelyezkedö löszös üledékben. Ennek körülbelül 30 \%a vázrészekhez köthető. A karbonát felhalmozódások eredetére vonatkozóan feltehetőleg pontosabb elképzelést lehetne kialakítani, amennyiben a felhalmozódás időtartamát, vagy korát meg tudnánk határozni.

A talajszelvényekbe ágyazott vázrészek karbonát tartalmát az üde, tömör dácitból meghatározott értékekkel összevetve azt tapasztaljuk, hogy a vizsgált szelvényben vázrészként előforduló dácit karbonát tartalma lényegesen nagyobb. Ez részben a kőzet porózusabb szerkezetének köszönhető, és arra utal, hogy a pórustérfogat egy részét a karbonát kiválás forrásaként szolgáló talajoldatok szintén átjárták.

\section{Köszönetnyilvánítás}

A terepi munkálatok elvégzéséhez szükséges anyagi hátteret az OTKA K101787 pályázat biztosította, a munkálatok részben védett és fokozottan védett területeken zajlottak, amelyekre a belépést és az ott folyó kutatást az ÉszakMagyarországi Környezetvédelmi Természetvédelmi, és Vízügyi Felügyelöség 16496-6/2011 számú határozatában (2011. okt. 10. Miskolc) engedélyezte. A karbonátos kérgekből készült csiszolatok elkészítésében nyújtott segítségért köszönetünket fejezzük ki Debus Déliának, a Miskolci Egyetem, ÁsványtaniFöldtani Intézet laboránsának. Köszönetünket fejezzük ki továbbá a Colas Északkő Bányászati Kft-nek, illetve Tarcal Község Önkormányzatának, hogy a tulajdonukban lévő területeken a kutatást számunkra lehetővé tették. A publikáció elkészítését a TÁMOP-4.2.2.B-15/1/KONV-2015-0001 számú projekt támogatta. A projekt az Európai Unió támogatásával, az Európai Szociális Alap társfinanszírozásával valósult meg.

Kulcsszavak: tokaji Nagy-hegy, másodlagos karbonátok, lösz, lejtőhordalék, termoanalitika 


\section{Irodalom}

BALLENEGGER, R., 1917. A tokaj-hegyaljai nyiroktalajokról. Földtani Közlemények 47(136): 20-24.

BITTó B., 1898a. A tokaj-hegyaljai szőlootalajok calciumcarbonat tartalmáról I-II, Magyar Chemiai Folyóirat, 4(8-9): 113-116; 129-137.

BiтTó B., 1898b. A tokaj-hegyaljai szőlőtalajok mésztartalmáról, Természettudományi Közlöny, 30 (344): 218.

Chaney, R.C., SLONIM, S.M., Slonim, S.S., 1982. Determination of Calcium Carbonate Content in Soils, in: ChANEY, R.C., DEMARS, K.R., 1982. Geotechnical properties, behavior, and performance of calcareous soils. American Society for Testing and Materials, Philadelphia-Baltimore. 3-16.

FAO 2006: Guidelines for soil description, Fourth edition, Rome, FAO, 97.

FEHÉR, O., FÜLEKY GY., MADARÁSZ B., KeRTÉSZ, Á., 2006. Hét vulkáni kőzeten kialakult talajszelvény morfológiai és diagnosztikai jellemzői a hazai genetikai talajosztályozás és a WRB (World Reference Base for Soil Resources, 1998) szerint. Agrokémia és Talajtan. 55 (2), 347-366.

FeKete, J., Stefanovits, P., BiDló, G., 1997. Comperative study of the mineral composition of red clays in Hungary. Acta Agronom. Hungarica. 45(4): 427441.

FÜleKY, Gy., JAKAB, S. , FEHÉR, O., MADARÁSZ, B., KERTÉSZ, Á., 2007. Hungary and the Carpathian Basin In: Arnalds, O., Bartoli, F., Buurman, P., Oskarsson, H., Stoops, G., García-Rodeja, E. (eds.) Soils of Volcanic Regions in Europe. Springer Verlag, Berlin Heidelberg, 29-42.

FÜLEKY, GY., KERTÉSZ,Á., MADARÁSZ,B., FEHÉR, O., 2004. Soils developed in volcanic material in Hungary. In: Óskarsson, H., Arnalds, Ó. (eds)(2004): Volcanic Soil Resources in Europe. Agricultural Research Institute, Reykjavík, 63-64

GYARMATI, P., 1977: A Tokaji-hegység intermedier vulkanizmusa. Magyar Állami Földtani Intézet Évkönyve, 58. Müszaki Kiadó, Budapest.

IUSS WORKING GROUP - FAO 2007: World Reference Base for Soil Resources - A Framework for International Classification, Correlation and Communication, IUSS Working Group WRB. World Soil Resources Reports No. 103. FAO, Rome (ISBN 92-5-105511-4), 128.

KERÉNYI, A., 1994. Loess erosion on the Tokaj Big-Hill. Quaternary International 24, 47-52.

MADARÁSZ, B., NÉMETH, T., JAKAB, G., SZALAI, Z., 2013. The erubáz volcanic soil of Hungary: Mineralogy and classification. Catena 107, 46-56.

NOVÁK T. J., INCZE, J., SPOHN, M., GLINA, B., GIANI, L., 2014. Soil and vegetation transformation in abandoned vineyards of the Tokaj Nagy-Hill. Catena 123: 8889. 
Pansu, M., Gautheyrou, J., 2006. Pipette Method after Robinson-Köhn or Andreasen. In: PANSU, M., GAUTHEYROU, J. 2006. Handbook of Soil Analysis: Mineralogical, Organic and Inorganic Methods. Springer Verlag Berlin Heidelberg pp. 35-42.

PINCZÉs, Z., 1954. A tokaji Nagyhegy lösztakarója. Földrajzi Értesítő 3, 575-584.

PonomareVA, V. V., Plotnikova, T. A., 1980. Gumus i Pochvoobrazovanie (Humus and Pedogenesis), Nauka, Leningrad. 65-74.

RózsA P., KozÁK M., 1982: A tokaji-nagyhegyi dácittípusok kőzettani viszonyai. Acta Geographica Debrecina, 20, 191-215.

SIMKÓ GY., 1926: Adatok a Tokaji-Nagyhegy és vidékének talajismeretéhez. Földtani Közlöny 56: 86-117.

STEFANOVITS, P., 1959. Vörösagyagok elöfordulása és tulajdonságaik Magyarországon.MTA Agrártudományi Osztályának Közleményei. 16: 225238.

SÜMEGI, P., 1995. Quartermalacological analysis of Late Pleistocene loess sediments of the Great Hungarian Plain. Malacological Newsletter 1, 79, 111.

SÜMEGI, P., HERTELENDI, E., 1998. Reconstruction of microenvironmental changes in the Kopasz Hill loess area at Tokaj (Hungary) between 15 and $70 \mathrm{ka}$ BP. Radiocarbon 40 (2), 855-863.

SzABó, J., 1866: Tokaj-Hegyalja talajának leírása s osztályozása, Mathematikai és természettudományi közlemények, 4(1): 366-372.

Xu, D., Cui, J., Bansal, R., Hao, X., Liu, J., Peterson, B. S., 2009. The Ellipsoidal Area Ratio (EAR): An Alternative Anisotropy Index for Diffusion Tensor Imaging. Magnetic Resonance Imaging. 27 (3):311-323. 


\title{
Vertical distribution and stocks of secondary carbonates in soil profiles from Tokaj
}

\author{
T. J. NOVÁK ${ }^{1}$, Á. CSÁMER ${ }^{2}$, J. INCZE ${ }^{1}$, I. PAPP ${ }^{2}$, P. RÓZSA ${ }^{2}$ \\ ${ }^{1}$ Department of Landscape Protection and Environmental Geography, \\ ${ }^{2}$ Department of Mineralogy and Geology, University of Debrecen
}

\begin{abstract}
Summary
The forms and stocks of secondary carbonate accumulations and the distribution of secondary carbonate content were investigated in 20 soil profiles from Nagy-hegy, Tokaj. The secondary carbonate content varied to a great extent under different lithological conditions. The frequency of carbonate crusts coating the coarse fragments to a thickness of 1-7 $\mathrm{mm}$ was especially conspicuous. In selected profiles the amount of secondary carbonates was analysed separately for three carbonate pools: in the fine earth $(<2 \mathrm{~mm})$, in carbonate crusts and other concentrations, and in the skeletal part of the soils (dominantly dacite blocks and boulders). In one profile a calculation was made of the calcium carbonate stocks (in $\mathrm{kg} \mathrm{m}^{-2}$ ) in the separate fractions of the fine earth, the skeletal fraction and the carbonate crusts and concentrations. The values obtained for the distinct soil horizons were then summed for the whole profile above the continuous hard rock.

The loess deposits can be regarded as the primary source of calcium carbonate, but many types of secondary carbonate accumulations occurred in places where the loess deposits were completely eroded or the original surface of the soil was only preserved on terraces with retaining walls. The results suggest that the highest accumulation of calcium carbonate occurs in profiles where loess, redeposited loess or colluvial deposit covers weathered volcanic rocks (pyroxene dacite), resulting in lithological discontinuity.

The carbonate crusts consisted of $55-96 \%(\mathrm{~m} / \mathrm{m}) \mathrm{CaCO}_{3}$, and the coarse fraction (dacite boulders and blocks) also had a higher calcium carbonate content $(5-10 \% \mathrm{~m} / \mathrm{m})$ than the non-weathered pyroxene dacite. The calcium carbonate stocks in Calcic accumulation horizons proved to be 2.5 times higher than in the overlying soil horizons.

The accumulation forms of carbonates in the soil profiles and the lack of loess deposits on the top of the soil profiles suggest that the calcium carbonate was accumulated in the transitional zone between the loess and the weathered volcanic rocks. This appears to have taken place under humid climatic conditions, unlike the recent climate, and can thus be regarded at least partially as the result of paleoecological processes.
\end{abstract}


Table 1. Grain size distribution and calcium carbonate content (mean \pm standard deviation) of samples from soil profiles developed on loess ( $\mathrm{N}=17)$ and in samples from soil profiles having lithological discontinuity at a shallow (within 100 $\mathrm{cm})$ depth $(\mathrm{N}=15)$.

Table 2. Concentration and stocks of carbonates, expressed as $\mathrm{CaCO}_{3}$ equivalent, for each diagnostic horizon and fraction in the T18 profile.

Figure 1. Photomicrograph of striped carbonate crust precipitated on the surface of a dacite fragment.

Figure 2. Distribution of calcium carbonate stocks and concentrations in the diagnostic horizons of the T18 profile (Colluvic-Regosol: Calcaric, Siltic, Escalic).

Figure 3. Hairline crack proceeding from the carbonate crust of a skeletal part is filled with calcite.

Keywords: Nagy-hegy, Tokaj, secondary carbonates, loess, colluvial deposit, thermal analysis 